\title{
Dietary encapsulated essential oil mixture influence on apparent nutrient digestibility, serum metabolic profile, lymphocyte histochemistry and intestinal morphology of laying hens
}

\author{
Cavit Arslan ${ }^{1, \star}$, Abdurrahman Pirinç$^{2}$, Nizamettin Eker ${ }^{2}$, Emrah Sur ${ }^{3}$, Ilknur Ündağ ${ }^{3}$, and Tansu Kuşat ${ }^{2}$
}

\author{
* Corresponding Author: Cavit Arslan \\ Tel: +90-536-388-23-54, \\ Fax: +90-332-241-00-63, \\ E-mail: cavitarslan@selcuk.edu.tr \\ ' Department of Animal Nutrition and \\ Nutritional Disease, Faculty of Veterinary \\ Medicine, Selcuk University, 42100 Campus \\ Selcuklu, Konya, Turkey \\ 2 Healty Science Institute, Selcuk University, \\ 42100 Campus, Selcuklu, Konya, Turkey \\ ${ }^{3}$ Department of Histology and Embryology, \\ Faculty of Veterinary Medicine, Selcuk \\ University, 42100 Campus, Selcuklu, Konya, \\ Turkey \\ ORCID \\ Cavit Arslan \\ https://orcid.org/0000-0002-1957-5520 \\ Abdurrahman Pirinç \\ https://orcid.org/0000-0002-9195-3792 \\ Nizamettin Eker \\ https://orcid.org/0000-0002-8785-090X \\ Emrah Sur \\ https://orcid.org/0000-0002-3513-7424 \\ ilknur Ündağ \\ https://orcid.org/0000-0001-8495-3930 \\ Tansu Kuşat \\ https://orcid.org/0000-0001-7237-1562
}

Submitted Jun 11, 2021; Revised Jul 20, 2021; Accepted Aug 27, 2021
Objective: The study aimed to evaluate the effects of a mixture of encapsulated essential oils (EOs) addition on nutrient digestion, serum biochemical parameters, peripheral blood alpha-naphthyl acetate esterase (ANAE), and acid phosphatase (ACP-ase) positive lymphocyte ratios and intestinal morphology in laying hens.

Methods: A total of 320 laying hens of 48-wk-old were randomly allotted into 4 treatment groups with 10 replicates of 8 birds in each replicate. The birds were fed a basal diet (control) or the diet added with mixture of EOs (which consist of eugenol, nerolidol, piperine, thymol, linalool, and geraniol) at 50,100 , and $200 \mathrm{mg} / \mathrm{kg}$ for period of 84 days.

Results: The addition of EOs at 100 or $200 \mathrm{mg} / \mathrm{kg}$ increased the dry matter, organic matter, and crude protein digestion as compared to control. The addition of all doses of EOs did not affect serum gamma glutamyl transferase, alanine aminotransferase, and $\mathrm{P}$ but increased serum asparate aminotransferase (AST) concentration. The addition of $200 \mathrm{mg} / \mathrm{kg}$ EOs increased serum creatinine, while $100 \mathrm{mg} / \mathrm{kg}$ decreased Ca concentration. The addition of 100 and $200 \mathrm{mg} / \mathrm{kg}$ EOs generally improved ANAE and ACP-ase positive peripheral blood lymphocyte ratios and intestinal morphology.

Conclusion: It can be concluded that, the addition of 100 or $200 \mathrm{mg} / \mathrm{kg}$ encapsulated EOs generally increased apparent nutrient digestion and serum AST concentration, improved ANAE and ACP-ase positive peripheral blood lymphocytes and intestinal morphology in laying hens.

Keywords: ACP-ase; Alpha-naphthyl Acetate Esterase (ANAE); Blood; Essential Oils Mixture; Intestinal Morphology; Laying Hens; Nutrient Digestibility

\section{INTRODUCTION}

Various subtherapeutic antibiotics have been used as feed additives since 1940 to enhance growth performance and prevent livestock disease, particularly in poultry. The uses of antibiotics in feed have been questioned due to the potential development of resistance in pathogenic bacteria and antibiotic residues in the animal tissues. Due to concern of transmission of this resistance to human pathogens through the food chain, all antibacterial feed additives are banned in the European Union in 2006. After the ban of antibiotics as feed additives, research has intensified on other feed additives of natural and herbal origin that do not leave residues in animal tissues. One of those alternatives is essential oils (EOs). Essential oils are volatile secondary metabolites abundant in aromatic plant families such as Lamiaceae and Apiaceae, containing many compounds such as monoterpenes and sesquiterpenes [1]. Aromatic plants contain a variety of functional bioactive compounds. Major compounds present in EOs are linalool (67.70\%), a-pinene (10.5\%), g-terpinene (9.0\%), geranyl acetate (4.0\%), camphor (3.0\%), and geraniol (1.9\%) [2]. It is recommended 
to use EOs in an encapsulated form because EOs are volatile compounds, and they are also sensitive to heat, light, UV light, moisture, $\mathrm{pH}$, metals and atmospheric oxygen, and deteriorate quickly leading to a decrease in active ingredients depending on the storage time [3]. Additionally, encapsulated EOs may slowly release their contents at controlled rates under specific conditions [4], which may prove more effective than their non-encaptulated form. Furthermore, it was suggested that the type of EOs has major influence on the growth performance of broilers, which reflects that different EOs are not effective equally for different response variables [5] so mixtures of EOs may be more effective as compared to the individual EO.

The mode of action of the bioactive compounds in EOs has not been fully explained. Various mechanisms have been suggested for a mode of action of EOs on nutrients digestion. Several authors have indicated that the use of EOs stimulates digestive enzyme (such as trypsin and amylase) activity [6], others a production and induction of a higher secretion of bile acids [7]. It has been reported that the addition of the various amount of EOs to the laying hen's diet did not affect dry matter (DM) digestion [8,9]. Radwan Nadia et al [10] detected that the addition of $0.5 \%$ to $1.0 \%$ of EOs from thyme, oregano, rosemary, or curcuma to laying hen's diet did not affect the digestibility of organic matter (OM). Yu et al [9] stated that adding different doses of anise oil (200, 400, and $600 \mathrm{mg} / \mathrm{kg}$ ) increased the digestibility of OM in laying hens. Although it has been determined in some studies that the addition of EOs increased digestibility of crude protein (CP) in laying hens $[8,9]$, whereas in another research no effect was found [10].

It was stated that the addition of thymol [11] and oregano EOs [12] to the laying hens' diets did not affect serum $\mathrm{Ca}$ and $\mathrm{P}$ concentrations.

Essential oils also have anti-inflammatory and immunemodulating properties, it was shown that clove oil, a major component of eugenol, increased humoral responses in human cell cultures [13]. Clove is also known as an immunomodulator that can induce lymphocyte proliferation and macrophage production [14]. Alpha-naphthyl acetate esterase (ANAE) demonstration has been widely used to differentiate $\mathrm{T}$ lymphocytes from B lymphocytes in some animal species, including chickens [15]. Positivity of acid phosphatase (ACP-ase) enzyme may also be used to identicate B lymphocytes in chicken [16].

It was demonstrated that the addition of oregano EOs to laying hens diets improved intestinal morphology [17], different levels of anise and thyme addition to broilers diet also induced an increase in duodenum, jejunum and ileum wall thickness [18].

The effect of EOs on apparent nutrient digestibility, blood serum metabolic profile and small intestinal morphology has been investigated in some previous studies. There is no complete accordance between the results obtained from these studies. The purpose of this study was to examine the effects of encapsulated EOs mixtures on the apparent digestibility (AD) of nutrients, blood serum metabolic profile, peripheral blood lymphocyte (PBL) histochemistry and gut morphology of the small intestine in laying hens.

\section{MATERIALS AND METHODS}

This study was carried out at Prof. Dr. Humeyra Ozgen Research and Application Farm, Faculty of Veterinary Medicine, Selcuk University (Konya, Turkey), in accordance with guidelines of the Selcuk University Animal Experiments Production and Research Committee (Date 27.03.2020, No: 2020/36).

\section{Experimental birds, diets, and management}

A total of 320 Nick Brown laying hens 48 weeks' old were used in this study. They were randomly divided into 4 treatment groups, each containing 80 birds. Ten replicates were set for each treatment, with 8 birds in each replicate.

The basal diet was formulated to meet nutrient requirements of Nick Brown laying hens recommended by NRC [19], and its ingredients and composition are shown in Table 1. A basal diet was supplemented with a commercial encapsulated EOs mixture (Agoline Poultry: Agolin S.A., Rte de la Picarde 20, 1145 Bière, Switzerland) at the concentrations of 0 (Control), 50 (EO-50), 100 (EO-100), and $200 \mathrm{mg} / \mathrm{kg}$ (EO200) respectively. The mentioned doses were based on the product. According to the declaration of the manufacturer, it is coated with hydrogenated sunflower oil by the spray cooling technique. The main ingredients of Agoline Poultry are as follows; $50.00 \%$ sunflower oil as carrier, approximately $20.00 \%$ active compounds consisting of linalool, eugenol, thymol, geraniol, nerolidol and piperine, and $30.00 \%$ other compounds such as organic acids, silica and syntetic antioxidants.

All hens were kept individually (one bird per cage) in environmentally controlled caged houses $(30 \times 45 \times 50 \mathrm{~cm})$ with temperature maintained at approximately $20^{\circ} \mathrm{C}$ to $24^{\circ} \mathrm{C}$. The house had controlled ventilation and lighting (16 L:8 D). All hens were fed with diets in granular form and water for ad libitum during the study. The study lasted for 12 weeks (48 to 60 weeks).

\section{Nutrient digestibility}

For the measurement of the nutrients' AD, 2 birds from each replicate (totally 20 birds per treatment group, 80 birds in total) were randomly selected on the 28th, 56th, and 84th day of the study. Excreta samples of each bird were collected and immediately stored at $-20^{\circ} \mathrm{C}$. During collection, care was 
Table 1. Ingredients and nutrient composition of the basal diet (\%)

\begin{tabular}{|c|c|c|c|c|}
\hline \multirow{2}{*}{ Item } & \multicolumn{4}{|c|}{ Dietary EOs concentration $(\mathbf{m g} / \mathbf{k g})^{1)}$} \\
\hline & 0 & 50 & 100 & 200 \\
\hline \multicolumn{5}{|l|}{ Ingredients } \\
\hline Barley & 7.15 & 7.15 & 7.15 & 7.15 \\
\hline Wheat & 5.20 & 5.20 & 5.20 & 5.20 \\
\hline Vegetable oil & 2.50 & 2.495 & 2.49 & 2.48 \\
\hline Sunflower meal & 3.77 & 3.77 & 3.77 & 3.77 \\
\hline Limestone & 8.71 & 8.71 & 8.71 & 8.71 \\
\hline Dicalcium phosphate & 1.80 & 1.80 & 1.80 & 1.80 \\
\hline Salt & 0.34 & 0.34 & 0.34 & 0.34 \\
\hline DL-Methionine & 0.09 & 0.09 & 0.09 & 0.09 \\
\hline \multicolumn{5}{|c|}{ Chemical composition, in DM } \\
\hline $\mathrm{DM}$ & 91.50 & 91.50 & 91.50 & 91.50 \\
\hline $\mathrm{ME}(\mathrm{MJ} / \mathrm{kg})^{3)}$ & 11.51 & 11.51 & 11.51 & 11.51 \\
\hline Organic matter & 89.44 & 89.44 & 89.44 & 89.44 \\
\hline Crude protein & 18.71 & 18.71 & 18.71 & 18.71 \\
\hline Calcium ${ }^{3)}$ & 3.83 & 3.83 & 3.83 & 3.83 \\
\hline Available phosphorus ${ }^{3)}$ & 0.41 & 0.41 & 0.41 & 0.41 \\
\hline Methionine+cystine ${ }^{3)}$ & 0.62 & 0.62 & 0.62 & 0.62 \\
\hline Lysine $e^{3)}$ & 0.75 & 0.75 & 0.75 & 0.75 \\
\hline Threonine $^{3)}$ & 0.61 & 0.61 & 0.61 & 0.61 \\
\hline Tryptophan ${ }^{3)}$ & 0.20 & 0.20 & 0.20 & 0.20 \\
\hline
\end{tabular}

EOs, essential oils; CP, crude protein; DM, dry matter; ME, metabolizable energy.

1) Control group was fed the basal diet. Treatment groups were fed same basal additonaly the diet supplemented with 50, 100, and 200 mg/kg of EOs, respectively.

2) Supplied per kg of diet: Vitamin A, 12,200 IU; cholecalciferol, 4,200 IU; vitamin E, $30 \mathrm{IU}$; vitamin K3; $4.5 \mathrm{mg}$, thiamine; 2.3 mg riboflavin; 8.8 mg, pantothenic acid; 7 mg pyridoxine; 4 mg cobalamin; 0.016 mg niacin; 30 mg choline chloride; 650 mg biotin; 0.20 mg folic acid, 0.25 mg Mn; 40 mg Fe; 58 mg Zn; 40 mg Cu; 8 mg l, 0.60 mg Se.

${ }^{3)}$ Calculated values in DM basis.

taken to avoid contamination from feathers, feed, and foreign materials. Excreta were dried at $80^{\circ} \mathrm{C}$ until constant weight. Diet and excreta were ground to pass through a 1 $\mathrm{mm}$ screen. Samples of the feed and excreta were analyzed for DM, CP (CP: N×6.25), ash and acid insoluble ash, as described by the AOAC [20]. The AD of DM, OM, and CP was determined by the acid insoluble ash ratio and $\mathrm{AD}$ of the nutrients was calculated using the following equation [21]:

$$
\begin{aligned}
\mathrm{AD}= & 100-[(\text { feed indicator \%/excreta indicator \% }) \\
& \times(\text { excreta nutrient \%/feed nutrient } \%) \times 100]
\end{aligned}
$$

\section{Blood sampling and laboratory analysis}

On the 84th day of the study, ten birds from each group (1 bird from each replicate) were randomly selected for blood collection, and blood was drawn from wing vein (Vena subcutenea ulnaris) using sterilized needles and syringes in vacutainer tubes for serum collection. Blood samples were allowed to standard for $2 \mathrm{~h}$ at room temperature to enable proper clotting. The samples were then centrifuged at 3,000 g×for 10 minutes. Serum gamma glutamyl transferase (GGT), asparate aminotransferase (AST), alanine aminotransferase (ALT), creatinine, $\mathrm{Ca}$, and $\mathrm{P}$ concentration was measured using commercially available test kits at an autoanalyzer (GEM Primer Plus 3000, 74351, Blood gas/ Electrolyte Analiser, Model 5700; Instrumental Laboratories, Bedford, MA, USA).

\section{Histochemistry}

Blood sampling: On the 84th day of the study, one bird from six subgroups $(1,2,3,4,5$, and 6$)$ was selected randomly on the basis of average live body weight of each subgroup for peripheral blood samples (6 birds from each group, totally 24 birds). The birds sacrificed by cervical dislocation and peripheral blood samples were collected during the cervical dislocation. Air-dried blood smears were used for ANAE 
and ACP-ase histochemistry and fixed in cold glutaraldehyde-acetone solution at $-10^{\circ} \mathrm{C}$ for $3 \mathrm{~min}$ rinsed three times in distilled water.

Demonstration and evaluation of histochemistry: Histochemical demonstrations of ANAE and ACP-ase were performed according to Maiti et al [15] and Sur and Celik [16], respectively. In the blood smears examined, some of the PBLs that were ANAE-positive showed one to three dot-like brown-reddish granules. Most of the PBL had strong ACP-ase positivity. The PBL containing one to three redpinkish cytoplasmic granules was considered ACP-ase positive. In smears stained for ANAE and ACP-ase, 200 lymphocytes were counted, and positive staining rates were calculated as the percentage of counted cells.

\section{Intestinal morphology}

Same 24 birds, which were used for peripheral blood sampling, were also used for intestinal histology. For this aim, after killing the birds whole gastrointestinal tracts were immediately removed and then $2 \mathrm{~cm}$ of intestinal segments were cut from the duodenum, jejunum and ileum. The segment of the duodenum was collected from $3 \mathrm{~cm}$ from the gizzard-duodenal junction point, whereas the jejunum segment was removed just above the Meckel diverticulum. Ileum samples were taken above the ileo-cecal junction [22]. All tissue samples were washed with pre-cooling physiological saline, and their contents were emptied without damaging their mucosa.

Tissue samples were fixed in 10\% buffered formaldehyde for 1 week. After the routine histological process, tissue samples were embedded in paraffin by using standard methods. From all paraffin blocks, 3 serial sections of $6 \mu \mathrm{m}$ thickness were taken. The sections were stained with Crossmon's triple stain [23] to determine the general histological structure and carried out the histometric measurements while periodic acid Schiff reaction [24] was performed to count goblet cell.

Measurements were made on randomly selected well-orientated 5 villi from different parts of 3 serial sections of each bird. Villus heights $(\mathrm{VH})$ were measured as the length from the tip to the base of villi. At the same time, the crypt depths (CD) were evaluated as the distance between the villi from the invagination started to the bottom end of the Lieberkühn glands. Villus widths (VW) were obtained by measuring at the half height point of the villi, while the thickness of the tunica muscularis (TTM) was determined by measuring the circular and longitudinal muscle layers together. The goblet cell counts (GCC) were obtained in 10 different areas of 100 $\mu \mathrm{m}$ line on sections performed PAS reaction.

All specimens were examined under the light microscope (Leica DM2500; Leica Microsystems GmbH, Wetzlar, Germany) and were photographed by a digital camera (Leica DFC 320) and recorded digitally for histometric analyses.

\section{Statistics}

All data were analysed by one-way analysis of variance (ANOVA) using SPSS version 16.0 statistic software (SPSS Institute Inc., Chicago, IL, USA). The significance of the differences among the groups was assessed by Duncan's multiple range test. Orthogonal polynomial contrasts were used to asses the significance of linear and quadratic models to describe the response of the dependent variable to a rising EOs levels. The difference between the nutrient digestibilities of the same group on the 28th, 56th, and 84nd days of the study was tested with the general linear model-repeated measures. The criterion of statistically significant for all data was at $\mathrm{p}$ values less than $\mathrm{p}<0.05$.

\section{RESULTS}

\section{Apparent nutrient digestibility}

The effect of dietary EOs on apparent nutrient digestibility is shown in Table 2. The $\mathrm{AD}$ of $\mathrm{DM}$ in the EO-200 group was higher than the other groups on the 28th day of the study (ANOVA, $\mathrm{p}<0.001$; linear, $\mathrm{p}<0.001$; quadratic, $\mathrm{p}<0.01$ ), it was higher in the EO-100 and EO-200 groups than the Control group on the 56th and 84th day of the study (ANOVA, $\mathrm{p}<0.001$; linear, $\mathrm{p}<0.001)$. When the $\mathrm{AD}$ of $\mathrm{DM}$ on the 28 th, 56 th, and 84th days of each group is compared within itself, it was higher in the EO-50 and EO-100 groups on the 56th day of the study than on the 28th and 84 th $d(p<0.01)$. Apparent digestibility of DM in the EO-200 group on the 84th days of the study was significantly higher than on the 28th and 56th day of the study $(\mathrm{p}<0.01)$.

The $\mathrm{AD}$ of $\mathrm{OM}$ in the EO-100 and the EO-200 groups were higher than the Control group on the 28th, 56th, and 84th days of the study (ANOVA, $\mathrm{p}<0.001$; linear, $\mathrm{p}<0.001$ ). When the apparent OM digestibility on the 28th, 56th, and 84th days of each group is compared within itself, it was higher only in the EO-50 group on the 56th day of the study than on the 28th and 84th $d(p<0.01)$.

The AD of CP in the EO-100 and EO-200 groups was higher than the Control group on the 28th, 56th, and 84th days of the study (ANOVA, $\mathrm{p}<0.001$; linear, $\mathrm{p}<0.001$ ). When the apparent CP digestibility on the 28th, 56th, and 84th days of each group was compared within itself, it was higher on the 56th day of the study in the EO-50 group than the 28th and 84th $d(p<0.05)$. Apparent digestibility of CP in the EO-100 group on the 56th day of the study was higher than on the 28th $d(p<0.05)$, it was higher in the EO-200 group on the 84th day of the study than on the 28th $\mathrm{d}(\mathrm{p}<0.001)$.

\section{Blood serum parameters}

The effect of dietary EOs on serum parameters is presented in Table 3. There were no statistical differences in the concentrations of GGT, ALT, and P among the groups. The 
Table 2. Effects of 0 (Control), 50 (EO-50), 100 (EO-100), and 200 mg/kg (EO-200) essential oil addition on apparent dry matter, organic matter and crude protein digestibility on 28th, 56th, and 84th day of the study, in DM \%, $(n=20)$

\begin{tabular}{|c|c|c|c|c|c|c|c|c|}
\hline \multirow{2}{*}{ Days } & \multicolumn{4}{|c|}{ Groups } & \multirow{2}{*}{ SEM } & \multicolumn{3}{|c|}{ p-value } \\
\hline & Control & EO-50 & EO-100 & EO-200 & & ANOVA & Linear & Quadratic \\
\hline \multicolumn{9}{|c|}{ Dry matter (d) } \\
\hline 28 & $69.74^{b}$ & $70.27^{\mathrm{bB}}$ & $71.10^{\mathrm{bB}}$ & $74.95^{\mathrm{aB}}$ & 0.376 & 0.000 & 0.000 & 0.008 \\
\hline 56 & $69.47^{c}$ & $72.06^{\mathrm{bA}}$ & $73.08^{\mathrm{bA}}$ & $75.11^{\mathrm{aB}}$ & 0.317 & 0.000 & 0.000 & 0.535 \\
\hline 84 & $69.93^{c}$ & $70.39^{\mathrm{bcB}}$ & $71.84^{\mathrm{bB}}$ & $75.97^{\mathrm{aA}}$ & 0.374 & 0.000 & 0.000 & 0.001 \\
\hline SEM & 0.253 & 0.295 & 0.418 & 0.259 & & & & \\
\hline$p$-value & 0.686 & 0.016 & 0.007 & 0.009 & & & & \\
\hline \multicolumn{9}{|c|}{ Organic matter $(\mathrm{d})$} \\
\hline 28 & $73.93^{c}$ & $74.44^{\mathrm{bcB}}$ & $75.99^{b}$ & $79.59^{a}$ & 0.396 & 0.000 & 0.000 & 0.016 \\
\hline 56 & $74.41^{\mathrm{C}}$ & $76.86^{\mathrm{bA}}$ & $77.03^{b}$ & $79.16^{a}$ & 0.274 & 0.000 & 0.000 & 0.807 \\
\hline 84 & $73.54^{\mathrm{c}}$ & $75.06^{\mathrm{CB}}$ & $76.94^{b}$ & $79.99^{a}$ & 0.383 & 0.000 & 0.000 & 0.170 \\
\hline SEM & 0.264 & 0.400 & 0.348 & 0.174 & & & & \\
\hline$p$-value & 0.339 & 0.010 & 0.133 & 0.300 & & & & \\
\hline \multicolumn{9}{|c|}{ Crude protein (d) } \\
\hline 28 & $50.08^{c}$ & $51.58^{\mathrm{bcB}}$ & $53.58^{\mathrm{bB}}$ & $56.22^{\mathrm{aB}}$ & 0.474 & 0.000 & 0.000 & 0.483 \\
\hline 56 & $51.29^{d}$ & $54.24^{\mathrm{CA}}$ & $55.92^{\mathrm{bA}}$ & $57.13^{\mathrm{aAB}}$ & 0.321 & 0.000 & 0.000 & 0.041 \\
\hline 84 & $51.06^{\mathrm{C}}$ & $52.48^{\mathrm{bcB}}$ & $54.70^{\mathrm{bAB}}$ & $57.69^{\mathrm{aA}}$ & 0.513 & 0.000 & 0.000 & 0.369 \\
\hline SEM & 0.277 & 0.379 & 0.668 & 0.232 & & & & \\
\hline$p$-value & 0.127 & 0.019 & 0.029 & 0.000 & & & & \\
\hline
\end{tabular}

Represents the total number of birds used for nutrient digestibility parameters from each group, $\mathrm{n}=20$.

SEM, pooled standard error of means; ANOVA, analysis of variance.

${ }^{a-d}$ Means in a row with different superscripts differ significantly.

$A, B$ Means in the same column with different superscripts differ significantly $(p<0.05)$.

concentration of AST was higher in all EOs groups than in the control (ANOVA, $\mathrm{p}<0.05$; linear, $\mathrm{p}<0.05$ ). The concentration of creatinine in the EO-200 group and Ca in the EO50 group were higher than the other groups (for creatinine ANOVA, $\mathrm{p}<0.001$; linear, $\mathrm{p}<0.001$; for Ca ANOVA, $\mathrm{p}<0.01$; linear, $\mathrm{p}<0.001$; quadratic, $\mathrm{p}<0.001$ ).

\section{Histochemical findings}

The mean ratios of the ANAE and $\mathrm{ACP}$-ase positive $\mathrm{PBL}$ are shown in Table 4. The ANAE positive lymphocyte ratio was higher in all EOs groups than the control (ANOVA, $\mathrm{p}<0.001$; linear, $\mathrm{p}<0.001$; quadratic, $\mathrm{p}<0.01)$. Although there were no statistical differences among ACP-ase ratios of the groups, it was numerically higher in the EO-100 group than the other groups (ANOVA, $\mathrm{p}>0.065$ ).

\section{Intestinal morphology}

The effects of EOs on histometric parameters in the small intestine segments (i.e., $\mathrm{VH}, \mathrm{VW}, \mathrm{CD}$, TTM, and the GCC in duodenum, jejunum, and ileum) of laying hens are presented in Table 4. The VH of duodenum in the EO-100 and EO-200 groups was higher than those of other groups (ANO-

Table 3. Effects of 0 (Control), 50 (EO-50), 100 (EO-100), and 200 mg/kg (EO-200) essential oils addition on some serum biochemical parameters on 84th day of the study, $(n=10)$

\begin{tabular}{|c|c|c|c|c|c|c|c|c|}
\hline \multirow{2}{*}{ Items } & \multicolumn{4}{|c|}{ Groups } & \multirow{2}{*}{ SEM } & \multicolumn{3}{|c|}{ p-value } \\
\hline & Control & EO-50 & EO-100 & EO-200 & & ANOVA & Linear & Quadratic \\
\hline \multicolumn{9}{|l|}{ Liver functions } \\
\hline GGT (U/L) & 26.1 & 26.6 & 26.7 & 26.9 & 0.48 & 0.950 & 0.580 & 0.882 \\
\hline AST (U/L) & $147^{b}$ & $167^{\mathrm{a}}$ & $166^{a}$ & $166^{\mathrm{a}}$ & 2.80 & 0.022 & 0.019 & 0.061 \\
\hline $\operatorname{ALT}(\mathrm{U} / \mathrm{L})$ & 1.37 & 1.10 & 1.50 & 1.50 & 0.10 & 0.413 & 0.363 & 0.235 \\
\hline \multicolumn{9}{|c|}{ Renal and muscle function } \\
\hline Creatinine (mg/dL) & $0.39^{b}$ & $0.39^{b}$ & $0.41^{b}$ & $0.45^{\mathrm{a}}$ & 0.01 & 0.001 & 0.000 & 0.061 \\
\hline \multicolumn{9}{|l|}{ Electrolytes } \\
\hline $\mathrm{Ca}(\mathrm{mg} / \mathrm{dL})$ & $31.4^{\mathrm{b}}$ & $33.3^{\mathrm{a}}$ & $29.2^{c}$ & $31.2^{b}$ & 0.36 & 0.006 & 0.004 & 0.001 \\
\hline$P(\mathrm{mg} / \mathrm{dL})$ & 5.31 & 5.79 & 5.99 & 5.42 & 0.12 & 0.168 & 0.095 & 0.641 \\
\hline
\end{tabular}

SEM, standard errors of means; ANOVA, analysis of variance; GGT, gamma glutamyl transferase; AST, asparate aminotransferase; ALT, alanine aminotransferase.

${ }^{a-c}$ Means in a row with different superscripts differ significantly $(p<0.05)$. 
Table 4. Effects of 0 (Control), 50 (EO-50), 100 (EO-100), and 200 mg/kg (EO-200) essential oils addition on lymphocyte histochemistry and small intestinal morphology of laying hens on 84th day of the study $(n=6)$

\begin{tabular}{|c|c|c|c|c|c|c|c|c|}
\hline \multirow{2}{*}{ Item } & \multicolumn{4}{|c|}{ Groups } & \multirow{2}{*}{ SEM } & \multicolumn{3}{|c|}{ p-value } \\
\hline & Control & EO-50 & EO-100 & EO-200 & & ANOVA & Linear & Quadratic \\
\hline \multicolumn{9}{|l|}{ Lymphocyte histochemistry } \\
\hline ACP-ase positive PBL (\%) & 69.00 & 68.17 & 76.17 & 70.17 & 1.20 & 0.065 & 0.247 & 0.245 \\
\hline \multicolumn{9}{|l|}{ Intestinal morphology } \\
\hline \multicolumn{9}{|l|}{ Duodenum } \\
\hline $\mathrm{CD}(\mu \mathrm{m})$ & $110.41^{c}$ & $93.69^{d}$ & $132.47^{\mathrm{a}}$ & $119.22^{b}$ & 1.92 & 0.000 & 0.000 & 0.546 \\
\hline $\mathrm{TTM}(\mu \mathrm{m})$ & $101.37^{a}$ & $77.39^{\circ}$ & $102.64^{a}$ & $88.96^{b}$ & 1.81 & 0.000 & 0.392 & 0.102 \\
\hline GCC (cell/100 $\mu \mathrm{m})$ & $6.28^{a}$ & $6.57^{\mathrm{a}}$ & $6.28^{a}$ & $5.72^{b}$ & 0.07 & 0.000 & 0.001 & 0.001 \\
\hline \multicolumn{9}{|l|}{ Jejunum } \\
\hline $\mathrm{VH}(\mu \mathrm{m})$ & $600.2^{\mathrm{a}}$ & $531.7^{\mathrm{b}}$ & $583.1^{\mathrm{a}}$ & $547.1^{b}$ & 6.31 & 0.000 & 0.042 & 0.169 \\
\hline \multicolumn{9}{|l|}{ Ileum } \\
\hline $\mathrm{VH}(\mu \mathrm{m})$ & 365.5 & 354.7 & 338.1 & 356.7 & 4.04 & 0.111 & 0.231 & 0.069 \\
\hline VW ( $\mu \mathrm{m})$ & $51.42^{d}$ & $56.06^{c}$ & $68.35^{a}$ & $63.03^{\mathrm{a}}$ & 1.00 & 0.000 & 0.000 & 0.003 \\
\hline $\mathrm{CD}(\mu \mathrm{m})$ & $64.72^{\text {bc }}$ & $62.75^{c}$ & $70.03^{\mathrm{ab}}$ & $71.20^{\mathrm{a}}$ & 1.02 & 0.006 & 0.003 & 0.423 \\
\hline $\operatorname{TTM}(\mu \mathrm{m})$ & $168.74^{\mathrm{a}}$ & $154.58^{\mathrm{a}}$ & $138.15^{b}$ & $163.27^{\mathrm{a}}$ & 2.79 & 0.000 & 0.164 & 0.000 \\
\hline GCC (cell/100 ㅆm) & 8.08 & 8.45 & 8.62 & 8.27 & 0.08 & 0.090 & 0.304 & 0.022 \\
\hline
\end{tabular}

SEM, standard errors of means; ANOVA, analysis of variance; ANAE, alpha-naphthyl acetate esterase; PBL, peripheral blood lymphocyte; ACP-ase, acid phosphatase; VH, villus height; VW, villus width; CD, crypt depth; TTM, thickness of tunica muscularis; GCC, goblet cell count.

${ }^{a-d}$ Means in a row with different superscripts differ significantly $(p<0.05)$.

VA, $\mathrm{p}<0.001$; linear, $\mathrm{p}<0.001)$. The VW of duodenum was lower in the EO-50 and EO-100 groups than in the other groups (ANOVA, $\mathrm{p}<0.001$; quadratic, $\mathrm{p}<0.001$ ). The $\mathrm{CD}$ of duodenum were higher in the EO-100 and EO-200 groups than the other group (ANOVA, $\mathrm{p}<0.001$; linear, $\mathrm{p}<0.001$ ). The TTM of duodenum was lower in the EO-50 and EO200 group than in the other groups (ANOVA, $\mathrm{p}<0.001$ ). The GCC of duodenum was lower in the EO-200 groups as compared to other groups (ANOVA, $\mathrm{p}<0.001$; linear, $\mathrm{p}<0.001$; quadratic, $\mathrm{p}<0.001)$.

The VH of jejunum was lower in the EO-50 and EO-200 groups than the other groups (ANOVA, $\mathrm{p}<0.001$; linear, $\mathrm{p}<0.05)$. The VW of jejunum was wider in the EO-100 than the Control and EO-50 groups (ANOVA, $\mathrm{p}<0.05$; linear, $\mathrm{p}<0.01)$. The $\mathrm{CD}$ of jejunum in the EO-100 group was higher than the other groups (ANOVA, $\mathrm{p}<0.001$; linear, $\mathrm{p}<0.05$; quadratic, $\mathrm{p}<0.001)$. The TTM of jejunum was lower in the EO-200 group than the other groups (ANOVA, $\mathrm{p}<0.001$; linear, $\mathrm{p}<0.001$ ), while the GCC was higher in all EO groups compared to control (ANOVA, $\mathrm{p}<0.001$; linear, $\mathrm{p}<0.001$; quadratic, $\mathrm{p}<0.001)$.

The addition of EOs did not affect $\mathrm{VH}$ of ileum, while VW increased in all EO groups compared to control (ANOVA, $p<0.001$; linear, $\mathrm{p}<0.001$; quadratic, $\mathrm{p}<0.001)$. The $\mathrm{CD}$ of ileum was higher in the EO-200 group than the EO-50 and Control groups (ANOVA, $\mathrm{p}<0.01$; linear, $\mathrm{p}<0.001$ ). The TTM of ileum was lower in the EO-100 group than those of other groups (ANOVA, $\mathrm{p}<0.001$; quadratic, $\mathrm{p}<0.001$ ). The GCC of ileum was quadratically higher in the EO-100 group than the Control (quadratic, $\mathrm{p}<0.05$ ).

\section{DISCUSSION}

\section{Apparent nutrient digestibility}

Apparent digestibility of DM varied between $69.47 \%$ and $75.97 \%$ in all groups on the 28th, 56th, and 84th days of the study (Table 2), which remained within the previously reported ranges $[9,25,26]$. The addition of $200 \mathrm{mg} / \mathrm{kg}$ EOs to diets on the 28th day of the study or 100 and $200 \mathrm{mg} / \mathrm{kg}$ on the 56th and 84th day of the study significantly increased DM digestion compared to Control. The increased DM digestion in the EO-100 and EO-200 groups indicated that the addition of high amounts of EOs (100 and $200 \mathrm{mg} / \mathrm{kg}$ ) increased DM digestion, whereas low amount $(50 \mathrm{mg} / \mathrm{kg}$ ) remain unchanged. In a previous study in broilers, addition of $200 \mathrm{mg} / \mathrm{kg}$ EOs or $5,000 \mathrm{mg} / \mathrm{kg}$ of Labiatae extract determined that Labiatae extract increased DM digestion during starter period, while both Labiatae extract and EOs increased 
it during finisher period [25]. It was also determined that the addition of 200, 400, and $600 \mathrm{mg} / \mathrm{kg}$ anise oil [9] and $0.5 \%$ and $1.0 \%$ of different EOs (i.e., thyme, oregano, rosemary, and curcuma) did not affect DM digestion in laying hens [10]. When the $\mathrm{AD}$ of $\mathrm{DM}$ at 28th, 56th, and 84th days of each treatment is evaluated within itself, there was an increase in the EO-50 and EO-100 groups on the 56th day of study, and also in the EO-200 group at the 84th day of study (Table 2).

In the present study, $\mathrm{AD}$ of $\mathrm{OM}$ ranged from $73.54 \%$ to $79.99 \%$ in all the groups on 28th, 56th, and 84 th days of the study (Table 2), which are consistent with other studies results $[9,26]$. The increased OM digestion in the EO-100 and EO-200 groups on the 28th, 56th, and 84th days of the study (Table 2) as compared to Control indicated that 100 or 200 $\mathrm{mg} / \mathrm{kg}$ EOs addition positively affected OM digestion in laying hens. Similarly, it was reported that the addition of 400 and $600 \mathrm{mg} / \mathrm{kg}$ EOs increased OM digestion compared to control in laying hens [9]. It was also detected that the addition of a blend of EOs at 80,125 , and $250 \mathrm{mg} / \mathrm{kg}$ had significant quadratic effects on OM of diets' total tract metabolic efficiency in male broilers [26]. Contrarily, it has been reported that the addition of 0.5 and $1.0 \%$ of various EOs to laying hen diets did not affect $\mathrm{OM}$ digestion [10]. When the $\mathrm{AD}$ of $\mathrm{OM}$ at 28th, 56th, and 84th days of each treatment is evaluated within itself, there was an increase in OM digestion only in the EO-50 group on 56th day of study (Table 2).

In this study, the $\mathrm{AD}$ of $\mathrm{CP}$ varied between $50.08 \%$ and $57.69 \%$ in all groups on the 28th, 56th, and 84th days of the study (Table 2). These results are in accordance with some previous studies $[8,25]$ but lower than those of others $[9,10$, $26,27]$. In general, it was noted that the addition of EOs to the diets increased the CP digestion by increasing the dose, in other word EOs addition showed a linear affect on the CP digestibility. This increase was significantly higher in the 100 and $200 \mathrm{mg} / \mathrm{kg}$ EOs added groups than the Control. The results indicated that a higher dose of EOs (100 and $200 \mathrm{mg} / \mathrm{kg}$ ) positively affected CP digestion in laying hens. Similarly, it was reported that the addition of $100 \mathrm{mg} / \mathrm{kg}$ [8] or $400 \mathrm{mg} / \mathrm{kg}$ [9] EOs to the laying hen diets increased CP digestion, while it did not change by lower or upper doses than above mentioned. Contrarily, it has been reported that the addition of $0.5 \%$ and $1.0 \%$ of EOs did not affect CP digestion in laying hens [10]. When the CP digestibility at 28th, 56th, and 84th days of each treatment is evaluated within itself, it reflects that in general CP digestion reached the highest ratio on 56th day of study (Table 2).

Based on the apparent nutrient digestibility data presented in this study, a generally improved nutrient digestibility could be postulated for the 100 and $200 \mathrm{mg} / \mathrm{kg}$ EOs treatments. Possible reasons for the increase in apparent nutrient utilization of 100 and $200 \mathrm{mg} / \mathrm{kg}$ EOs added groups might be associated with better secretion of digestive enzymes. One of the main active compound of EOs used in this study is piperine, which stimulates digestive enzymes $[7,28]$. Gao et al [29] found that encapsulated blends of EOs $(150,200$, and $250 \mathrm{mg} / \mathrm{kg}$ diet) enhanced jejunal mucosal $\alpha$-amylase and chymotrypsin activity, improved intestinal morphology, and promoted the performance of broilers. A study conducted by adding 50,100, and $150 \mathrm{mg} / \mathrm{kg}$ oregano EOs to laying hen diets determined that $100 \mathrm{mg} / \mathrm{kg}$ increased amylase and trypsin activity but did not affect lipase activity. It was also observed that EOs had positive effects on increasing the secretions of digestive enzymes and intestinal mucous in the gut, thus improving the digestibility of the feeds $[7,30]$. Therefore, the improvement of nutrient utilization in this study may be caused by the stimulative effect of the EOs on the secretions of the endogenous digestive enzymes and the increased absorption surface area of the small intestine (Table 4).

\section{Blood serum parameters}

The biochemistry evaluation of liver enzymes (such as AST, ALT, GGT) gives evidence about metabolic disorders caused by diseases or nutritional deficiency that influence hepatic activity. The GGT is an enzyme found in many organs throughout the body, with the highest concentrations found in the liver. It is elevated in the blood in most diseases that cause damage to the liver or bile ducts. The GGT can indicate cholestasis and biliary duct proliferation in the chicken liver [31]. In this study, serum GGT concentration varied between 26.1 and 26.9 U/L in all groups (Table 3). Our results are similar to results of Gonçalves et al [31] who reported 17.37 to 35.02 $\mathrm{U} / \mathrm{L}$ before and during the peak of egg production respectively.

The AST enzyme is considered a responsive marker in liver disorder in chicken, even if it is a nonspecific parameter [31]. In the present study, serum AST concentration ranged between 147 and $167 \mathrm{U} / \mathrm{L}$ in all groups (Table 3), which is similar to the results of Lokaewmanee et al [32], higher than Mousavi et al [33] and Abo Ghanima et al [34] and lower than that of Bolukbasi et al [35]. Our results indicated that the addition of all EOs doses increased the serum AST concentration as compared to Control. The increase in AST concentration in all the EOs added group might be due to increased feed intake because of high egg production during the study period. Gonçalves et al [31] reported that increasing feed intake causes a higher overload in the liver of commercial laying hens; thus, serum levels of AST enzyme increase. Enhanced AST and ALT activities are generally considered a biomarker of hepatic damage or dysfunction [36], tissue disturbance, and increased membrane permeability and liver enzymes escaping to blood serum [31]. In this study, no interpretation could be made because a histo-pathological 
examination was not performed in the liver tissue. Contrarily, in many previous studies, it has been reported that the addition of EOs to diet did not affect $[10,17,32,35]$ or decreased serum AST concentration in laying hens $[33,34]$.

In this study, serum ALT concentration changed between 1.10 and $1.50 \mathrm{U} / \mathrm{L}$ among the groups (Table 3 ), which are similar to results of previous studies $[32,35]$. Our results indicated that the addition of all doses of EOs to the diet did not affect the serum ALT concentration. Similarly, in previous studies conducted in laying hens, it was determined that the addition of EOs did not affect the serum ALT concentration $[10,17,32]$. Contrarily, it was found that 100 and 200 $\mathrm{mg} / \mathrm{kg}$ EOs mixture [33] and $300 \mathrm{mg} / \mathrm{kg}$ rosemary or cinnamon decreased serum ALT concentrations in laying hens [34].

Creatinine, a by-product of phosphocreatine breakdown in skeletal muscle, is an important indicator of protein metabolism [37] and an index of renal function [38]. Its blood levels are related to muscle mass, age, physical activity, and diet [39]. In the current study, serum creatinine concentration ranged between 0.39 and $0.45 \mathrm{mg} / \mathrm{dL}$ among the groups (Table 3), which is similar to the results of other studies [34, 38]. Our results indicated that only $200 \mathrm{mg} / \mathrm{kg}$ EOs addition to the diet increased serum creatinine concentration when compared to other groups. The higher serum creatinine concentration in the EO-200 group might be related to the higher apparent $\mathrm{CP}$ digestion in this group (Table 2). In many previous studies, it was determined that the addition of EOs did not affect the serum creatinine concentration in laying hens $[17,32,34]$.

In this study, serum Ca concentration varied 29.2 to 33.3 $\mathrm{mg} / \mathrm{dL}$ all the groups (Table 3 ), which is similar to the results of previous studies $[17,32]$ but higher than that of Bolukbas 1 et al [35]. Our results indicated that the addition of $50 \mathrm{mg} / \mathrm{kg}$ EOs to the diet increased serum Ca concentration, $100 \mathrm{mg} / \mathrm{kg}$ decreased and $200 \mathrm{mg} / \mathrm{kg}$ unchanged as compared to Control. The result reflected that $50 \mathrm{mg} / \mathrm{kg}$ EOs improved the bio-availability of $\mathrm{Ca}$ in laying hens. Similarly, it was determined that 400 and $600 \mathrm{mg} / \mathrm{kg}$ oregano EOs [17] and 300 $\mathrm{mg} / \mathrm{kg}$ rosemary or cinnamon [34] increased serum Ca concentration, whereas 0.5 and $1.0 \mathrm{mg} / \mathrm{kg}$ bergamot oil decreased it [35], but $250 \mathrm{mg} / \mathrm{kg}$ thymol [11] and $24 \mathrm{mg} / \mathrm{kg}$ oregano EOs [12] did not change serum Ca concentration in laying hens. It was reported that EOs could positively affect serum $\mathrm{Ca}$ and $\mathrm{P}$ concentration probably by improving intestinal morphology and oxidative stress or by increasing intestinal $\mathrm{pH}$ [40]. However, Yoon et al [41] indicated that piperine, which is one of the active compounds of used EOs in this study, inhibits the activity of Ca2-ATP-ase enzyme in transporting the calcium ions across the cell membrane that will decrease calcium.

In the present study, serum $\mathrm{P}$ concentration ranged between 5.31 to $5.99 \mathrm{mg} / \mathrm{dL}$ among the groups (Table 3), which is similar to the results of previous studies [17,35] but higher than those of others $[11,12,32,34]$. Our results indicated that the addition of 50, 100, and $200 \mathrm{mg} / \mathrm{kg}$ EOs to the diet did not affect serum P concentration. Similarly, it was reported that different EOs supplementation to diet did not influence serum $\mathrm{P}$ concentration in laying hens $[11,12,32,35]$. Contrarily, it was determined that EOs addition increased serum $\mathrm{P}$ concentration in laying hens $[17,34]$.

In general, possible reasons for some of the differences in blood serum parameters between this study and other studies might be due to the dose of EOs used in diets, the different active substances in EOs, the strain and age of the birds used in the research, the nutritional contents of the diets and the differences in feeding programs.

\section{Histochemistry}

Lymphocytes have a vital role in body protection against infection and are known as mediator cells of the adaptive immune response and are divided into B- and T-lymphocytes. B-lymphocytes are responsible for antibody-production, and their maturation process occurs in the bone marrow and bursa of Fabricius in mammals and avian species, respectively. However, T-lymphocytes are responsible for cellular immunity, and the maturation of $\mathrm{T}$ lymphocytes occurs in the thymus in both mammals and avian species [42]. Awaad et al [43] demonstrated that some EOs stimulated the immune response in chickens. In this study, it was observed that 50, 100, and $200 \mathrm{mg} / \mathrm{kg}$ EOs addition increased the ANAE positive lymphocyte ratios (Table 4). As known ANAE positive lymphocyte is accepted T-cell the increase may reflect an improvement of cellular immunity. We could not compare our ANAE positivity results due to the lack of study. However, Lee et al [44] observed proliferation of spleen lymphocytes and increasing peripheral blood T-lymphocytes in chicken fed a diet containing phytogenic mixture.

The ACP-ase positive lymphocyte is accepted B cell in chicken, which is responsible for humoral immunity [16]. Our result showed that although there was no statistical difference, 100 and $200 \mathrm{mg} / \mathrm{kg}$ EOs addition numerically increased the ratio of ACP-ase positive lymphocyte $(\mathrm{p}<0.065)$. Lee et al [44] determined that there were higher serum antibody titers against some certain Eimeria species in chicken fed a diet containing phytogenic additives. Although the immunomodulatory effects of EOs are known, the mechanism of their biological action still remains obscure. Wael et al [14] have reported that Syzygium aromaticum leaf extract increased the proliferative activity of lymphocytes in $\mathrm{Balb} / \mathrm{c}$ mice infected with Salmonella typhimurium. Kim et al [45] claimed that the addition of some phytogenic additives altered gene expression of certain cytokines in the intestinal intraepithelial lymphocytes of chickens. 


\section{Intestinal morphology}

Generally, it is accepted that increased thickness of the intestinal mucosa, especially $\mathrm{VH}$ and $\mathrm{VW}$, are correlated by an increased digestive and absorptive function of the small intestine due to enlarged absorptive surface area. Our results indicated that the addition of 100 and $200 \mathrm{mg} / \mathrm{kg}$ EOs increased the VH of the duodenum, while 50 and $200 \mathrm{mg} / \mathrm{kg}$ decreased the VH in the jejunum, but none of the EOs affected VH in the ileum (Table 4). The addition of 50 and 100 $\mathrm{mg} / \mathrm{kg}$ EOs decreased VW in the duodenum; only $100 \mathrm{mg} / \mathrm{kg}$ EOs increased VW of jejunum. The VW of ileum was higher in the all EOs group than the Control. Our results on the $\mathrm{VH}$ and $\mathrm{VW}$ are in accordance with Gul et al [17] who used oregano oil in laying hens. Similarly, Sur et al [22] demonstrated that especially high level mint addition increased $\mathrm{VH}$ but decreased VW in all small intestinal segments in Japanese quails.

Intestinal glands, also called Lieberkühn crypts, extend down from the base of the villi to the muscular mucosa. Undifferentiated epithelial cells located in these glands enlarge intestinal mucosal surface area and renew intestinal epithelium by dividing and migrating to villi [18]. Many authors have shown that an increase in the depth of the crypts, which serve as a cell source for the intestinal epithelium, is an indicator of cell renewal rate. There are opposing views about $\mathrm{CD}$, and some researchers claimed that the deep crypts also reflect the long villi $[46,47]$ while some others argued that increasing CD shows faster cellular turnover in response to inflammation or epithelial cell shedding [29]. In general, the addition of $50 \mathrm{mg} / \mathrm{kg}$ EOs causes a decrease in CD in all segments of the small intestine, whereas $100 \mathrm{mg} / \mathrm{kg}$ increased. However, $200 \mathrm{mg} / \mathrm{kg}$ EOs increased CD of duodenum and ileum but decreased of jejunum. In agreement with this study, it was reported that the addition of organic acids and EOs improved the villi number, $\mathrm{VH}$ and $\mathrm{CD}$ of the small intestine in broiler chicken [48]. It was also demonstrated that a high level mint addition increased CD in all segments of the small intestine in Japanese quails [22]. However, in another study it was determined that EOs addition did not influence $\mathrm{VH}$ and $\mathrm{CD}$, but $\mathrm{VH}: \mathrm{CD}$ ratio was higher in broiler chickens [49]. Gao et al [29] found that the mixture of EOs and organic acids decreased CD-length in the duodenum and jejunum but increased VH:CD ratio of 21-day-old broilers as compared to control. In an experimental study it was found that the addition of EOs mixture increased $\mathrm{VH}$ and $\mathrm{VH}: \mathrm{CD}$ ratios of jejunum [50].

Tunica muscularis is responsible for intestinal motility resulting in peristalsis, which is an involuntary movement. Peristalsis has a crucial role in the passage of food mixture along the intestinal tract. This movement increases the enzymatic activity on nutrients by mixing of contents; finally these processes improve the absorption of nutrients [51]. In the present study, the tendency of a decrease in TTM of all small intestinal segments was generally observed. Contrarily, in many studies adding high level oregano oil or mint addition increased the TM layer [17,22].

Goblet cells are scattered within the enterocytes, producing the mucin [18]. Mucin coats the gastrointestinal tract, and it is accepted as the first-line host defense. These cells in the intestinal mucosa provide lubricity via mucin which also acts as a protective barrier against pathogenic microorganisms [52]. Gao et al [46] reported that the increase in the GCC may be related to the increase in the $\mathrm{CD}$, which reflects epithelial regeneration. Additionally, Wang et al [53] reported that an increase in the GCC due to Bifidobacteria can cause the secretion of mucin- 2 and may enhance the intestinal mucosal immune function of birds. However, it was suggested that GCC increase is related to mucosal damage. In addition, the increase caused decrease nutrient absorption and increased extra energy consumption [54]. In this study, there was a decrease in GCC of the duodenum in the EO-200 group as compared to other groups (Table 4). However, GCC in the jejunum in all EOs groups was higher than control. Generally, GCC increased tendency depending on the EOs level in the ileum, but it was only higher in the EO-100 group than the control. Similarly, Hamedi et al [47] has shown a significant increase in GCC of jejunum and ileum of birds fed with diets containing sunflower meal. Sur et al [22] also demonstrated that high level mint supplementation increased GCC in the ileum of Japanese quails.

\section{CONCLUSION}

In conclusion, the addition of 100 , and especially $200 \mathrm{mg} / \mathrm{kg}$, of a mixture of encapsulated EOs in laying hens diet, improved $\mathrm{DM}, \mathrm{OM}$, and $\mathrm{CP}$ digestion, but $50 \mathrm{mg} / \mathrm{kg}$ did not influence these parameters. The addition of 50, 100, and 200 $\mathrm{mg} / \mathrm{kg}$ EOs did not affect serum GGT, ALT, and P concentration but increased the serum AST concentration. The addition of $50 \mathrm{mg} / \mathrm{kg}$ and $200 \mathrm{mg} / \mathrm{kg}$ EOs increased Ca and creatinine concentration, respectively. But $100 \mathrm{mg} / \mathrm{kg}$ decreased serum $\mathrm{Ca}$ concentration. The addition of EOs to laying hens diet generally increased the ANAE and ACP-ase positive $\mathrm{PBL}$ ratio, and this increase might be an immunomodulatory effect in laying hens. There was great variability in small intestinal morphology depending on the EOs treatment. When the intestinal histology findings are evaluated as a whole, it can be said that the addition of 100 and 200 $\mathrm{mg} / \mathrm{kg}$ EOs improved the intestinal morphology, and this improvement could positively affect nutrient absorption. It can be concluded that, the improved nutrient digestion, ANAE and ACP-ase positive lymphocyte ratio, intestinal morphology addition of a mixture of encapsulated EOs 100 and $200 \mathrm{mg} / \mathrm{kg}$ (which containing eugenol, nerolidol, piperine, thymol, lin- 
alool, and geraniol as active compounds) has a beneficial effect in laying hens. Futher studies should be done to find the most optimum dose rate of encapsulated EOs between 100 and $200 \mathrm{mg} / \mathrm{kg}$.

\section{CONFLICT OF INTEREST}

We certify that there is no conflict of interest with any financial organization regarding the material discussed in the manuscript.

\section{FUNDING}

This research was produced from a study supported by Selcuk University Scientific Research Support Coordinatory (Project number: 2019-19202087).

\section{REFERENCES}

1. Rajeshwari U, Andallu B. Medicinal benefits of coriander (Coriandrum sativum L). Spatula DD 2011;1:51-8.

2. Khani A, Rahdani T. Chemical composition and insecticidal activity of essential oil from Coriandrum sativum seeds against tribolium confusum and Callosobruchus maculatus. Int Sch Res Notices 2012;2012:Article ID 263517. https://doi. org/10.5402/2012/263517

3. Nehme R, Andrés S, Pereira RB, et al. Essential oils in livestock: from health to food quality. Antioxidants 2021;10:330. https:// doi.org/10.3390/antiox10020330

4. Hosseini S, Meimandipour A. Feeding broilers with thyme essential oil loaded in chitosan nanoparticles: an efficient strategy for successful delivery. Br Poult Sci 2018;59:669-78. https://doi.org/10.1080/00071668.2018.1521511

5. Chowdhury S, Mandal GP, Patra AK. Different essential oils in diets of chickens: 1 . Growth performance, nutrient utilisation, nitrogen excretion, carcass traits and chemical composition of meat. Anim Feed Sci Technol 2018;236:86-97. https://doi.org/10.1016/j.anifeedsci.2017.12.002

6. Jang IS, Ko YH, Yang HY, et al. Influence of essential oil components on growth performance and the functional activity of the pancreas and small intestine in broiler chickens. Asian-Australas J Anim Sci 2004;17:394-400. https://doi.org/ 10.5713/ajas.2004.394

7. Platel K, Srinivasan K. Digestive stimulant action of spices: a myth or reality? Indian J Med Res 2004;119:167-79.

8. Ding X, Yu Y, Su Z, Zhang K. Effects of essential oils on performance, egg quality, nutrient digestibility and yolk fatty acid profile in laying hens. Anim Nutr 2017;3:127-31. https://doi.org/10.1016/j.aninu.2017.03.005

9. Yu C, Guo Y, Yang Z, Yang W, Jiang S. Effects of star anise (Illicium verum Hook.f.) essential oil on nutrient and energy utilization of laying hens. Anim Sci J 2018;90:880-6. https:// doi.org/10.1111/asj.13221

10. Radwan Nadia L, Hassan RA, Qota EM, Fayek HM. Effect of natural antioxidant on oxidative stability of eggs and productive and reproductive performance of laying hens. Int J Poult Sci 2008;7:134-50. https://doi.org/10.3923/ijps. 2008.134.150

11. Abdel-Wareth AAA. Effect of dietary supplementation of thymol, synbiotic and their combination on performance, egg quality and serum metabolic profile of Hy-Line Brown hens. Br Poult Sci 2016;57:114-22. https://doi.org/10.1080/ 00071668.2015.1123219

12. Bozkurt M, Bintas E, Kurkan S, et al. Comparative evaluation of dietary supplementation with mannan oligosaccharide and oregano essential oil in forced molted and fully fed laying hens between 82 and 106 weeks of age. Poult Sci 2016;95: 2576-91. https://doi.org/10.3382/ps/pew140

13. Halder S, Mehta AK, Mediratta PK, Sharma KK. Essential oil of clove (Eugenia caryophyllata) augments the humoral 1mmune response but decreases cell mediated immunity. Phytother Res 2011;25:1254-6. https://doi.org/10.1002/ptr. 3412

14. Wael S, Watuguly TW, Arini I, et al. Potential of Syzygium aromaticum (Clove) leaf extract on immune proliferation response in Balb/c mice infected with Salmonella typhimurium. Case Rep Clin Med 2018;7:613-27. https://doi.org/ $10.4236 / \mathrm{crcm} .2018 .712057$

15. Maiti NK, Saini SS, Sharma SN. Histochemical studies on chicken peripheral blood lymphocytes. Vet Res Commun 1990;14:207-10. https://doi.org/10.1007/BF00347739

16. Sur E, Celik I. Effects of aflatoxin B1 on the development of the bursa of Fabricius and blood lymphocyte acid phosphatase of the chicken. Br Poult Sci 2003;44:558-66. https://doi.org/ $10.1080 / 00071660310001618352$

17. Gul M, Yilmaz E, Sezmis G, Yıldırım BA, Kaya A, Onel SE. Effect of oregano (Oreganum syriacum L.) essential oil and cage density on performance parameters, egg quality criteria, some blood biochemical parameters, blood antioxidant capacity, and intestinal histopathology in laying hens. GSC Biolog Pharm Sci 2020;13:136-45. https://doi.org/10.30574/ gscbps.2020.13.2.0370

18. Al-Mashhadani EH, Al-Tememy HSA, Al-Jaff FK, Al-Mashhadani HE. Effect of supplementation broiler diet with anise and thyme essential oils on histological changes of small intestine. Egypt Poult Sci 2013;33:249-59.

19. National Research Council. Nutrient requirements of poultry. 9th Ed. Washington, DC, USA: National Academy Press; 1994.

20. AOAC. Official methods of analysis of AOAC International. 11th Ed. Gaithersburg, MD, USA: AOAC International, 2000.

21. Coskun B, Seker E, Inal F. Feeds and their technologies. 3rd Ed. Konya, Turkey: Selcuk University Faculty of Veterinary Medicine Publication Unit; 2000. 
22. Sur E, Caglayan T, Kadiralieva N, Seker E. Determination of the effects of Mentha caucasica on histology of small intestine in Japanese quail (Coturnix coturnix japonica). Eurasian J Vet Sci 2017;33:248-54.

23. Crossmon G. A modification of Mallory's connective tissue stain with a discussion of the principles involved. Anat Rec 1937;69:33-8. https://doi.org/10.1002/ar.1090690105

24. Cook HC. Carbonhydrates, In: Bancroft JD, Stewens A, editors. The theory and practice of histological techniques. 3rd ed. Edinburgh, UK: Churchill Livingstone; 1990. pp. 143-53.

25. Hernandez F, Madrid J, Garcia V, Orengo J, Megias MD. Influence of two plant extracts on broilers performance, digestibility, and digestive organ size. Poult Sci 2004;83:16974. https://doi.org/10.1093/ps/83.2.169

26. Mountzouris KC, Paraskevas V, Tsirtsikos P, et al. Assessment of a phytogenic feed additive effect on broiler growth performance, nutrient digestibility and caecal microflora composition. Anim Feed Sci Technol 2011;168:223-31. https://doi.org/10.1016/j.anifeedsci.2011.03.020

27. Amad AA, Manner K, Wendler KR, Neumann K, Zentek J. Effects of a phytogenic feed additive on growth performance and ileal nutrient digestibility in broiler chickens. Poult Sci 2011;90:2811-6. https://doi.org/10.3382/ps.2011-01515

28. Khajuria A, Thusu N, Zutshi U. Piperine modulates permeability characteristics of intestine by inducing alterations in membrane dynamics: Influence on brush border membrane fluidity, ultrastructure and enzyme kinetics. Phytomedicine 2002;9:224-31. https://doi.org/10.1078/0944-7113-00114

29. Gao YY, Zhang XL, Xu LH, Peng H, Wang CK, Bi YZ. Encapsulated blends of essential oils and organic acids improved performance, intestinal morphology, cecal microflora, and jejunal enzyme activity of broilers. Czech J Anim Sci 2019; 64:189-98. https://doi.org/10.17221/172/2018-CJAS

30. Jang IS, Ko YH, Kang SY, Lee CY. Effect of a commercial essential oil on growth performance, digestive enzyme activity, and intestinal microflora population in broiler chickens. Anim Feed Sci Tech 2007;134:304-15. https://doi.org/10. 1016/j.anifeedsci.2006.06.009

31. Gonçalves FM, Ribeiro EM, Montagner P, et al. Serum levels of liver enzymes in laying hens before and during the peak of egg production. Acta Sci Vet 2010;38:311-4.

32. Lokaewmanee K, Yamauchi K, Komori T, Saito K. Eggshell quality, eggshell structure and small intestinal histology in laying hens fed dietary Pantoea- $6^{\star}$ and plant extracts. Ital J Anim Sci 2014;13:3163. https://doi.org/10.4081/ijas.2014. 3163

33. Mousavia A, Mahdavia AH, Riasia A, Soltani-Ghombavani M. Synergetic effects of essential oils mixture improved egg quality traits, oxidative stability and liver health indices in laying hens fed fish oil. Anim Feed Sci Technol 2017;234: 162-72. https://doi.org/10.1016/j.anifeedsci.2017.10.001

34. Abo Ghanima MM, Elsadek MF, Taha AE, et al. Effect of housing system and rosemary and cinnamon essential oils on layers performance, egg quality, haematological traits, blood chemistry, 1mmunity, and antioxidant. Animals 2020; 10:245. https://doi.org/10.3390/ani10020245

35. Bolukbası SC, Urusan H, Erhan MK, Kiziltunc A. Effect of dietary supplementation with bergamot oil (Citrus bergamia) on performance and serum metabolic profile of hens, egg quality and yolk fatty acid composition during the late laying period. Arch Geflügelk 2010;74:172-7.

36. Botsoglou NA, Taitzoglou IA, Botsoglou E, Lavrentiadou SN, Kokolı AN, Roubies N. Effect of long-term dietary administration of Oregano on the alleviation of carbon tetrachloride-induced oxidative stress in rats. J Agric Food Chem 2008;56:6287-93. https://doi.org/10.1021/jf8003652

37. Piotrowska A, Burlikowska K, Szymeczko R. Changes in blood chemistry in broiler chickens during the fattening period. Folia Biol (Kraków) 2011;59:183-7. https://doi.org/ 10.3409/fb59_3-4.183-187

38. Marono S, Loponte R, Lombardi P, et al. Productive performance and blood profiles of laying hens fed Hermetia illucens larvae meal as total replacement of soybean meal from 24 to 45 weeks of age. Poult Sci 2017;96:1783-90. https://doi. org/10.3382/ps/pew461

39. Rajman M, Jurani M, Lamosova D, et al. The effects of feed restriction on plasma biochemistry in growing meat type chickens (Gallus gallus). Comp Biochem Physiol A Mol Integr Physiol 2006;145:363-71. https:/doi.org/10.1016/ j.cbpa.2006.07.004

40. Placha I, Ocelova V, Chizzola R, et al. Effect of thymol on the broiler chicken antioxidative defence system after sustained dietary thyme oil application. Br Poult Sci 2019;60:589-96. https://doi.org/10.1080/00071668.2019.1631445

41. Yoon YC, Kim SH, Kim MJ, Yang HJ, Rhyu MR, Park JH. Piperine, a component of black pepper, decreases eugenolinduced cAMP and calcium levels in non-chemosensory 3T3-L1 cells. Febs Open Bio 2015;5:20-5. https://doi.org/10. 1016/j.fob.2014.11.008

42. Leena C, Prasad RV, Kakade K, Jamuna KV. Age related histochemical changes of the bursa and thymus of domestic fowl. J Vet Anim Sci 2009;40:9-11.

43. Awaad MHH, Abdel-Alim GA, Sayed KSS, et al. Immunostimulant effects of essential oils of peppermint and eucalyptus in chickens. Pak Vet J 2010;30:61-6.

44. Lee SH, Lillehoj HS, Jang SI, Lee KW, Bravo D, Lillehoj EP. Effects of dietary supplementation with phytonutrients on vaccine-stimulated immunity against infection with Eimeria tenella. Vet Parasitol 2011;181:97-105. https://doi.org/10. 1016/j.vetpar.2011.05.003

45. Kim DK, Lillehoj HS, Lee SH, Jang SU, Bravo D. High-throughput gene expression analysis of intestinal intraepithelial lymphocytes after oral feeding of carvacrol, cinnamaldehyde, or Capsicum oleoresin. Poult Sci 2010;89:68-81. https://doi. 
org/10.3382/ps.2009-00275

46. Gao J, Zhang HJ, Yu SH, et al. Effects of yeast culture in broiler diets on performance and immunomodulatory functions. Poult Sci 2008;87:1377-84. https://doi.org/10.3382/ps.200700418

47. Hamedi S, Rezaian M, Shomali T. Histological changes of small intestinal mucosa of cocks due to sunflower meal single feeding. Am J Anim Vet Sci 2011;6:171-5. https://doi.org/10. 3844/ajavsp.2011.171.175

48. Stamilla A, Messina A, Sallemi S, et al. Effects of microencapsulated blends of organics acids (OA) and essential oils (EO) as a feed additive for broiler chicken. A focus on growth performance, gut morphology and microbiology. Animals 2020;10:442. https://doi.org/10.3390/ani10030442

49. Bosetti GE, Griebler L, Aniecevskı E, et al. Microencapsulated carvacrol and cinnamaldehyde replace growth-promoting antibiotics: effect on performance and meat quality in broiler chickens. Annals Braz Acad Sci 2020;92:e20200343. https:// doi.org/10.1590/0001-3765202020200343

50. Pham VH, Kan L, Huang J, et al. Dietary encapsulated essential oils and organic acids mixture improves gut health in broiler chickens challenged with necrotic enteritis. J Anim Sci Biotechnol 2020;11:18. https://doi.org/10.1186/s40104-0190421-y

51. Cetingül IS, Rahman A, Uluca A, et al. Effect of Mentha piperita on some morphological characteristics of intestine in Japanese quails (Coturnix coturnix japonica). Archiva Zootech 2015;18:53-60.

52. Theerawatanasirkul S, Koomkrong N, Kayan A, Boonkaewwan C. Intestinal barrier and mucosal immunity in broilers, Thai Betong, and native Thai Praduhangdum chickens. Turk J Vet Anim Sci 2017;41:357-64.

53. Wang H, Liang S, Li X, Yang X, Long F, Yang X. Effects of encapsulated essential oils and organic acids on laying performance, egg quality, intestinal morphology, barrier function, and microflora count of hens during the early laying period. Poult Sci 2019;98:6751-60. https://doi.org/10.3382/ps/pez391

54. Nourmohammadi R, Afzali N. Effect of citric acid and microbial phytase on small intestinal morphology in broiler chicken. Ital J Anim Sci 2013;12:e7. https://doi.org/10.4081/ijas.2013.e7 